\title{
Gender Patterns in Labor Allocation to Avocado Production: Evidence from Kenya
}

\author{
Edna G. Johnny, \\ Jane Kabubo-Mariara, \\ Richard Mulwa, \\ George M. Ruigu, \\ University of Nairobi, Kenya
}

Doi:10.19044/esj.2019.v15n22p31 ～URL:http://dx.doi.org/10.19044/esj.2019.v15n22p31

\begin{abstract}
Farmers face gender differentiated unique social and economic circumstances which may in part determine their time allocation behavior. Using primary survey data from Murang'a County, Kenya, this study employs the double hurdle and Tobit models to investigate gendered patterns of labor allocation in avocado production under contract and non-contract scenarios, non-farm activities as well as the intensity of time use. Results show that while avocado commercialization through contract farming has to some extent altered traditional gender roles in farming, there is still limited participation of women in avocado marketing under contract farming. Hence, interventions aimed at enhancing smallholder avocado production should incorporate mechanisms that will enable women participate at all levels of the avocado value chain.
\end{abstract}

Keywords: Gender patterns, Labor, Avocado, Double hurdle

\section{Introduction}

Agriculture is a key sector in Kenya's economy, contributing 32.6 percent to Gross Domestic Product (GDP). It also contributes about 27 per cent indirectly through the manufacturing and other service-related sectors (KIPPRA, 2017). Agricultural activities are dominated by smallholder farmers most of whom produce on farms averaging 0.2-3 hectares (Republic of Kenya, 2010). Production critically depends on intra-household division of labor in which gender is the fulcrum around which these divisions occurs. Women play a significant role in commercial as well as subsistence food production, contributing about 60 to 80 percent of labor in households and in agricultural production (Republic of Kenya, 2010). Women farmers are however faced with multiple constraints that limit their productivity. According to the 
National Agriculture and Livestock Extension Programme (NALEP, 2009), about 95 of women working in the agricultural sector simply farm the land and graze livestock but have minimal control in terms of decisions on farming inputs and marketing, credit access or how income from farming are spent. Women also have low asset ownership and face unequal division of labor. The report further iterated that women farmer's needs are not clearly captured or prioritized by government policies that dictate productivity in the agricultural sector particularly in the extension services.

Reducing gender inequality in agriculture by addressing inefficiencies that perpetuate gender based constraints in production especially for crops with high market potential has been recognized as a pathway of enhancing the competiveness and sustainability of agriculture (OECD, 2008). One of such crop with growing national and global demand that have the potential to provide employment opportunity and a stable source of income for smallholder farmers is avocado farming in Kenya. Avocado has become one of the major exports and foreign exchange earner contributing to growth of the horticulture fruit sub-sector (HCD, 2016). Some years back, the fruit was produced mostly for local consumption. Today, production and market trends have significantly changed due to increasing local and global demand for the fruit. Kenya is an important exporter of avocado in the European market with 85 percent of all fruit export produced by smallholders (HCD, 2010). The competitive advantage Kenya has over other exporting countries in Hass variety harvesting season when none of the leading producers have fruits, provides new opportunities for both men and women producers and makes the crop ideal for rural poverty reduction.

In Kenya like many other African settings, culturally defined gender ideologies define tasks and responsibilities in crop cultivation as well as access to resources and decision making on production (Wane, 2014). Although both men and women are involved in production, avocado trees are mainly owned by male household heads (Oduol et al., 2014). As owners of the trees, they make production, marketing and income decisions and also negotiate avocado contract farming agreements (Oduol et al., 2014). Studies on avocado value chain indicated that the role of women is not fully recognized by other chain actors due to lack of ownership rights to avocado trees (Mutiso, 2017). As such, they are excluded from avocado agronomy and Good Agricultural Practice (GAP) certification trainings and from the export value chain (Oduol et al., 2014). The exclusion of women farmers is affirmed by Dolan (2001) whose study of French beans in Kenyan indicated that production value chains involving commercialization tend to exclude women even where they are the main farmers.

With the growing market and export potential of the fruit, promoting gender inclusive production will ensure that women farmers are not 
disadvantaged in production. Additionally, Kenya's avocado export potential in terms of meeting quantity requirements to maintain market share in face of global competition depends on the efficient and effective participation of male and female farmers in production, thus, strengthening production and marketing systems for the sustainability of the avocado sector requires disentangling the gender effect of their respective roles.

Also, the effects of globalization coupled with economic and social transformations as well as migration of male farmers in search of off-farm opportunities have substantially shaped the reorganization of household farms, and specifically the gender division of labor and responsibilities in crop production in Kenyan agriculture (Eerdewijk and Danielsen, 2015). These dynamisms may likely influence the availability of labor to perform critical tasks in avocado production. The implication is that ensuring the active participation of women farmers at all levels of the avocado production cycle requires an understanding of how these relationships affect gender patterns in production. There is however a paucity of such information in empirical research.

Previous studies have investigated different facets of production and marketing of avocado. For instance, Gyau et al., (2016) analyzed factors that determine collective action and how it influences avocado production and marketing; Omolo et al., (2011) investigated avocado marketing in TransNzoia district and Oduol et al. (2014) assessed women's participation along the avocado value chain in Kandara sub-county and Marani district. While these studies investigated interlinkages within the avocado value chain, the primary facet of production and structural changes within the household that may hamper production of the fruit and resulting market participation have not been addressed. Moreover, little is known on how various exogenous factors affect gender roles in avocado production and trade-offs made with other economic activities. Against this backdrop, this study investigates gender patterns in labor allocation to avocado production in Kenya. The paper seeks to answer the following research questions: What factors explain gender patterns in labor allocation to avocado production and other economic activities? What is the intensity of time use in these activities by gender? What is the role of avocado contract farming on gender labor allocation?

This paper contributes to gender, agriculture and labor literature by firstly providing a framework that models gender differences in labor allocation to avocado production as well as to other off-farm activities as a two stage procedure of participation and intensity of participation. Secondly, this study explicitly assesses the role of avocado contract farming on gender labor allocation. Thirdly, this analysis informs policies related to opportunities and constraints experienced by male and female avocado farmers for which appropriate interventions can be planned. 
The rest of the paper is structured as follows. Section 2 discusses empirical review of gender patterns in labor allocation. Section 3 presents empirical strategy. Section 4 describes data. Section 5 presents the results and the last section concludes

\section{Empirical review of gender patterns in labor allocation}

The study of Boserup (1970) pointed out that women's labor allocation to crops intended for subsistence consumption resulted in their exclusion from the exports market thus perpetuating marginalization and poverty of women. Various studies accessing labor allocation to farm and off-far activities suggested that off-farm activities compliment farm production by providing income for purchase of needed farm inputs; it however withdraw family labor from needed farming activities (Babatunde, 2015). Fafchamps and Quisumbing (2003) analysis of social roles and intra-household division of labor within rural households in Pakistan showed that gender and family status significantly influenced intra-household labor allocation to various activities. Ilahi (2001) investigation of male and female time use in various activities in Peru revealed that age, marital status, and ethnicity were important factors that determined intra-household time allocation. The author further reiterated that women spent most of their time doing housework while their male counterparts spent theirs in non-farm income generating activities. Schindler (2008) study of time allocation to farm and non-farm activities in relation to gender and norms in post-war genocide Rwanda found that educational attainment and wealth status significantly lowered the intensity of household labor allocation to agricultural activities.

Sikei et al., (2009) assessment of factors that influenced how household labor was allocated to fuel wood collection, agriculture and nonfarm activities in Kakamega forest, Kenya, revealed that education, landholdings, distance and household size were significant in explaining household labor allocation decisions. Similarly, (Haggblade et al., 2010) examination of the rural non-farm economy suggested that education of households was significantly linked to agricultural productivity. In subSaharan Africa, Palacios-Lopez et al., (2015) showed that female labor share in crop production averaged around 40 percent but country wide estimates varied. Also, the intensity of involvement of women in cash crop production also differed across countries. Qualitative case study analysis conducted by Eerdewijk and Danielsen (2015) for maize production in Ethiopia and Kenya found that men's involvement in agriculture is changing and declining and that in female-headed households, tillage, land preparation, weeding, post-harvest management and transport are done by female members of the household. The studies of (Fafchamps and Quisumbing, 2003; Ilahi, 2001; Schindler, 2008; Sikei et al., 2009; Eerdewijk and Danielsen, 2015; Palacios-Lopez et al., 2015) 
did not however disentangle participation and the extent of involvement in those activities. This paper assesses gendered pattern in labor allocation to avocado production and other economic activities using estimation procedures that takes into account the interrelatedness between participation and intensity of time use time use but as separate decisions.

\section{Methodology}

To examine gender patterns in labor allocation to avocado production, the study relies on the linear labor supply function specified as:

$$
L_{a i}=X_{a i}{ }^{\prime} \beta+\varepsilon_{a i}
$$

Where $L_{a i}$ is the dependent variable representing the share of household labor allocated by males and females to avocado production, other farming activities, wage and non-farm self-employment, $X_{a i}$ is set of covariates , $\beta$ is a vector of parameters to be estimated and $\varepsilon_{a i}$ is the stochastic error term assumed to be distributed normally. This model is typically estimated by ordinary least squares (OLS) which assumes complete participation. Ideally, individuals in farm households often make decisions on which activities to allocate their time and how much time to spend. Consequently, there end up being activities with no time allocated to them thus causing the dependent variable to be constrained with some clustering at zero.

To circumvent the issue of no time allocated to some activities, (thus zeros in the dependent variable), this study used the Tobit and Double Hurdle (DH) models. The Tobit model permits the estimation of censored dependent variables by combining both probit and ordinary least squares (OLS) models to demarcate non-participants and participants and to assess the behavioral characteristics of participants. The Tobit model proposed by Tobin (1958) assumes that participation and intensity decisions are made as a single process and that zeros are interpreted as corner solution.

The double hurdle model proposed by Cragg (1971) relaxes the Tobit assumptions by allowing participation and intensity decisions to be made as separate stochastic processes and the possibility of zeros in both outcomes. It is reasonable in this study to assume that individual's time use in avocado production and other activities could be due to social, demographic and cultural concerns rather than just economic. For instance, there may be zeros in the intensity equation since farming activities are most often divided within the household along age or gender considerations.

The DH model (Cragg, 1971) assumes that participation and intensity are separate decisions determined by different latent variables. The time decision is modeled as probit while the level of time in each activity is modelled as a Tobit. Innocent and Young, (2004) have shown that although 
the double hurdle approach has been widely applied to migration and agricultural technological adoption studies (Simtowe and Zeller, 2007) it is also suitable for labor supply decisions studies. With this guidance and following Jones (1989 and 1992) this study estimates gendered labor allocation decisions to avocado production and other economic activities using the DH model specified below.

$$
\begin{aligned}
& Y_{1 i}^{*}=z_{i}^{\prime} \alpha+\varepsilon_{i} \quad Y_{1 i}^{* *}=1\left[Y_{1 i}^{*}>0\right] \text { (Participation decision) } \\
& Y_{2 i}^{*}=X_{i}^{\prime} \beta+u_{i} \quad Y_{2 i}^{* *}=\max \left(0, Y_{2 i}^{*}\right) \quad \text { (Intensity decision) }
\end{aligned}
$$

The two hurdles are linked to give the share of observed labor days $\left(Y_{i}\right)$ allocated to each activity specified as:

$$
Y_{a i}=Y_{1 i}^{* *} Y_{2 i}^{* *}
$$

Where $Y_{1 i}^{*}$ is the latent variable denoting utility derived from participation in each activity, $Y_{1 i}^{* *}$ is participation hurdle, where one denotes participation and zero otherwise, $Y_{2 i}^{*}$ is the latent variable denoting the utility derived from the amount of time allocated to each activity, $Y_{2 i}^{* *}$ is the intensity hurdle denoting the latent share of labor time allocated to each activity, $Y_{a i}$ is observed share of labor time allocated to activities by individual $i$. $Z$ and $X$ are vectors of covariates which includes household and individual characteristics, physical and financial endowments, social capital and community characteristics posited to influence both participation and intensity decision, $\alpha$ and $\beta$ are parameters to be estimated, while $\varepsilon_{i}$ and $u_{i}$ are error terms which are randomly distributed as bivariate normal distribution. Assuming correlated errors based on the work of Jones, (1992), the likelihood for estimating the $\mathrm{DH}$ is specified as:

$$
L=\prod_{0}\left[1-\varpi\left(\mathrm{z}_{i}^{\prime} \alpha, \frac{x_{i} \beta}{\sigma}, \rho\right)\right] \prod_{+}\left[\Phi\left(\frac{z_{i}^{\prime} \alpha+\frac{\rho}{\sigma}\left(\mathrm{y}_{i}-x_{i} \beta\right)}{\sqrt{1-\rho^{2}}}\right) \frac{1}{\sigma} \phi\left(\frac{\left(\mathrm{y}_{i}-x_{i} \beta\right)}{\sigma}\right)\right]
$$

Where $\varpi($.$) is the bivariate normal cumulative distribution function$ (CDF), $\Phi_{(.)}$is the conditional CDF, $\phi_{(.)}$is the univariate normal probability density function(PDF), $\rho, \beta, \sigma$ and $\alpha$ are parameters that can be estimated 
simultaneously. If the correlation coefficient $\rho=0$, the model becomes similar with Cragg's independent double hurdle. If on the other hand $\rho=0, x$ $=z$ and $\alpha=\beta / \sigma$, then with no censoring or selection present, the double hurdle model reduces to a Tobit model which is the sum of the log likelihood of the probit model representing the first part and truncated normal regression model the second part.

The double hurdle model is estimated by Maximum Likelihood methods which readily derives the Hessian matrix and the score vectors. To handle positively skewed data, the study used the natural logarithmic transformation following Newhouse (1987). With the natural log transformation, the positive time allocated remains positive while zero time allocation without transformation remains as the truncated part. Transformation of the dependent variable to the natural logarithm form is more responsive for the computation of elasticities than other non-linear transformations (Newhouse, 1987).

Three marginal effects which include: i) the probability of participation ii) the unconditional expected mean showing the total effect on the explained variable and iii) the conditional expected mean expected level of time allocated based on participation are normally derived from the DH model to partition the effect of covariates. With regards to exclusion restrictions, the double hurdle model of Cragg's (1971) did not give any guidance on variables that should be included in both equations as in the case of Type 2 Tobit where exclusion restrictions are stipulated for model identification. This study therefore used socio-economic and demographic variables such as household characteristics, physical and financial endowments, social capital and distance to market posited to influence both participation and intensity decisions (Gyau et al. 2016; Palacios-Lopez et al. 2015). The overarching hypothesis is that females and males face different sets of constraints which determine their labor allocation behavior to various activities.

\section{Data and descriptive statistics}

The data for the empirical analysis was collected as part of a research project on "Productive Employment in the Segmented Markets (PRESM) for Fresh Produce" funded by the Dutch Science Foundation (NWO). The project was implemented by the Partnership for Economic Policy (PEP) in collaboration with the VU-University of Amsterdam and University Amsterdam/Amsterdam Institute for Global Health and Development (AIGHD)-University of Amsterdam, University of Nairobi, Fresh Produce and Exporters Association of Kenya (FPEAK), Grupo de Análisis para el Desarrollo (GRADE) and PRIME-ITC (coordinated by LEI Wageningen UR) 
in November-December 2015 in Murang'a County, Kenya. A multistage sampling approach was used to select the county, sub-county, villages and households. In the first stage Murang'a County in Central region of Kenya was purposefully selected from 47 counties because it is the main avocado producing county in Kenya. Kandara sub-county was then selected in the second stage from seven sub-counties of Murang'a County. This sub-county was selected because it is the main avocado producing sub-county in Murang'a and the County government has thrown its weight behind avocado production. Besides, the County has experienced substantial expansion in avocado production over the previous ten years in both volume and exports and was therefore found to provide an interesting case study to analyze the implications for rural development.

In the final stage, a sampling frame of avocado growers in the county was provided by the Kandara sub-county agricultural office from which a total of 790 households were randomly selected. From the sampled households, 266 were engaged in avocado contract farming while 525 were non-contract farmers. Data on labor allocation to avocado and other agricultural production activities, wage employment and non-farm self-employment was collected through a year recall. Household heads were asked about the participation and the amount of time spent by each adult member 15 years and above on production. Further, data was collected on the amount of time spent by adult members in physical, management and marketing activities. The total number of adults in these households comprised of 1,109 females and 1,086 males.

The dependent variable for participation is a dummy, coded as one for participation and zero otherwise. The dependent variable for intensity is continuous and captures the level of time spent in avocado production, other farming activities (maize, beans, banana, mango, tea, coffee, cassava, and other livestock production), wage employment and non-farm selfemployment. Labor for avocado and other crops are defined as time allocated to land preparation, weeding and pest control, harvesting, threshing/winnowing and marketing. Wage labor is defined as skilled or unskilled labor time allocated to agricultural and non-agricultural activities while non-farm self-employment labor is defined as labor allocated to physical, management and marketing/sales activities that do not generate wage or salary earnings.

Descriptive statistics in Table 1 gives the mean values of dependent and independent variables used in the analysis for both males and females. The independent variables consist of both individual and household characteristics. From the descriptive analysis, adults in our sample spent a relatively greater share of their labor time, equivalent to 47.6 percent, on other farming activities. This is an aggregation of time spent on other crops. Of the remaining labor time, about 18.5 percent was spent on wage employment, 17.0 
percent on avocado production, and 16.8 percent on non-farm selfemployment. In avocado production activities, males spent more labor days in marketing activities than their female counterparts.

The data showed that males had more years of education than females but more females than males had farming as their main occupation. The proportion of males that received training was three times larger than females. On the other hand, males more than females voted for leaders elected in avocado groups. About 19 percent of adults were credit constraint. Male household heads on average attained more education than female heads. On the other hand, more female heads ( 81 percent compared to 78 percent males) had farming as their main occupation. Households with children aged between zero to five and six to fourteen years represent 13 and 61 percent of the sample respectively. The mean value of both agricultural and non-agricultural assets was Ksh39, 945 and households on average owned 2 acres of land. About 35 percent of households owned livestock and covered about 3.7 kilometers distance to the market.

Table 1: Descriptive Statistics

\begin{tabular}{|c|c|c|c|c|c|c|}
\hline \multirow[b]{2}{*}{ Dependent Variables } & \multicolumn{2}{|c|}{$\begin{array}{l}\text { Females } \\
\mathrm{N}=1,109 \\
\end{array}$} & \multicolumn{2}{|c|}{$\begin{array}{c}\text { Males } \\
\mathrm{N}=1,086\end{array}$} & \multicolumn{2}{|c|}{$\begin{array}{c}\text { All Adults } \\
2,195\end{array}$} \\
\hline & Mean & SD & Mean & SD & Mean & SD \\
\hline Avocado Production & 0.170 & 0.199 & 0.170 & 0.196 & 0.170 & 0.197 \\
\hline Other Crop farming & 0.479 & 0.354 & 0.472 & 0.355 & 0.476 & 0.355 \\
\hline Wage Employment & 0.184 & 0.330 & 0.187 & 0.330 & 0.185 & 0.330 \\
\hline Non-farm Self- Employment & 0.167 & 0.331 & 0.171 & 0.334 & 0.169 & 0.332 \\
\hline \multicolumn{7}{|l|}{ Gender division of work in Avocado Farming } \\
\hline Land Preparation & 12.205 & 15.373 & 11.584 & 13.935 & 11.898 & 14.676 \\
\hline Weeding & 8.493 & 11.534 & 7.589 & 10.969 & 8.046 & 11.261 \\
\hline Harvesting & 15.540 & 22.230 & 16.401 & 25.369 & 15.967 & 23.828 \\
\hline Marketing & 4.264 & 7.982 & 5.173 & 10.855 & 4.712 & 9.517 \\
\hline \multicolumn{7}{|l|}{ Independent variables } \\
\hline \multicolumn{7}{|l|}{ Individual characteristics } \\
\hline Age of adults (years) & 47.892 & 19.584 & 47.724 & 20.990 & 47.809 & 20.288 \\
\hline Educational attainment (years) & 7.986 & 3.798 & 9.273 & 3.474 & 8.623 & 3.697 \\
\hline Main Occupation (farming=1) & 0.734 & 0.442 & 0.642 & 0.480 & 0.689 & 0.463 \\
\hline Age of household head (years) & 61.350 & 13.338 & 60.725 & 13.293 & 61.036 & 13.317 \\
\hline Educational attainment of head(years) & 8.260 & 3.834 & 8.648 & 3.594 & 8.455 & 3.720 \\
\hline Main occupation of head(farming=1) & 0.819 & 0.385 & 0.786 & 0.410 & 0.802 & 0.398 \\
\hline Marital status (married=1) & 0.537 & 0.499 & 0.567 & 0.496 & 0.551 & 0.497 \\
\hline Credit constrained (yes $=1$ ) & 0.197 & 0.398 & 0.182 & 0.386 & 0.189 & 0.392 \\
\hline Participated in contract farming $($ yes $=1)$ & 0.341 & 0.474 & 0.331 & 0.471 & 0.336 & 0.472 \\
\hline Non-labor income $($ yes $=1)$ & 0.297 & 0.457 & 0.275 & 0.447 & 0.286 & 0.452 \\
\hline Received training $($ yes $=1$ ) & 0.203 & 0.411 & 0.654 & 0.405 & 0.427 & 0.408 \\
\hline $\begin{array}{l}\text { Number of avocado meeting attended in in } \\
12 \text { months }\end{array}$ & 8.012 & 7.557 & 9.100 & 0.363 & 8.553 & 8.103 \\
\hline
\end{tabular}




\begin{tabular}{|c|c|c|c|c|c|c|}
\hline Voted for leaders in avocado group $($ yes $=1)$ & 0.460 & 0.481 & 0.613 & 0.474 & 0.537 & 0.477 \\
\hline \multicolumn{7}{|l|}{ Household Characteristics } \\
\hline Number of children $(0-5)$ & 0.129 & 0.389 & & & & \\
\hline Number of children (6-14) & 0.614 & 0.949 & & & & \\
\hline Value of assets (Ksh) & $39,945.13$ & 113831.6 & & & & \\
\hline Total land owned (acre) & 2.097 & 1.927 & & & & \\
\hline Owned livestock size (TLU) & 0.355 & 0.374 & & & & \\
\hline Distance to market $(\mathrm{km})$ & 3.71 & 9.261 & & & & \\
\hline
\end{tabular}

\section{Empirical Results and Discussions}

5.1 Factors influencing participation and the intensity of time use by gender

The probability and intensity of participation can be modeled in a Tobit framework which assumes that the factors influencing the probability are similar to those influencing the intensity. Alternatively, one can model a double hurdle model where the two stages are separated and Tobit is nested in the double hurdle. From our model diagnostic tests, results indicated that the Tobit model is nested within the double hurdle model. Secondly, the appropriateness of the double hurdle model is validated by the significant correlation coefficient between unobservable factors of the first hurdle (participation decision) and the second hurdle (intensity of participation) for all activities measured by sigma which suggest a robust dependence between the two tiers. The factors influencing probability of participation and intensity of time use are classified broadly into household characteristics, ownership of physical and capital assets, and social capital. Regression results for participation and intensity of time use are presented in Tables 2 and 3, respectively.

Based on these results, the probability of female participation in avocado production is much higher for younger women; and as they advance in age, their participation and time use became more aligned to non-farm selfemployment. Male participation and time use in avocado production is not affected by aging. Age however reduced their time in farming but increased time in wage employment. Education does not influence female participation and time use in avocado production. However, the probability of female participation in other crop farming increased with education. This could be explained by the fact that females find it difficult to find jobs in non-farm sectors or the returns from other crops may be higher compared to non-farm employment. Education however influences male allocation to labor, as an additional year of education increased the probability of males substituting time spent in wage employment with avocado production. This could be due to the fact that the expected benefit from producing avocado which has increasing national and global demand provides higher payoff for education 
than wage employment. This supports Sikei et al. (2009) who concluded that household reallocation of labor from non-farm self-employment to agricultural activities is in response to the returns from such activities. The probability of female participation in other crop farming also increased with education. This could be explained by the fact that females find it difficult to find jobs in non-farm sectors, while returns from working on own farm may be higher compared to non-farm employment.

The results further indicated that females from male headed households had a better chance of working in wage employment than in farm activities as compared to their peers in female headed households. The substitution effect of female time use could probably be explained by the fact that in male-headed households, the availability of male labor affords female members the opportunity to allocate time to wage employment. Thus women in female headed households maybe constrained from exploring other nonfarm opportunities due to the shortage of male labor for farming activities. Furthermore, it was found that in households with children below age five, female members were less likely to be in wage employment compared to males. The result further showed that unlike males, female members are more likely to reduce their time share in avocado production with the presence of young kids in the home. These gender differences in participation and time use stemming from household composition and care responsibilities may have costly implications particularly for female members (Ilahi, 2000; Schindler, 2008). 
Table 2: Average Partial Effects of Double Hurdle Model for Determinants of Participation

\begin{tabular}{|c|c|c|c|c|c|c|c|c|}
\hline \multirow[b]{2}{*}{ Variable } & \multicolumn{8}{|c|}{ Probit marginal Effect of Participation } \\
\hline & $\begin{array}{r}\text { Avc } \\
\text { Prod }\end{array}$ & $\begin{array}{l}\text { cado } \\
\text { ction }\end{array}$ & \multicolumn{2}{|c|}{$\begin{array}{l}\text { Other Crop } \\
\text { Production }\end{array}$} & \multicolumn{2}{|c|}{$\begin{array}{c}\text { Wage } \\
\text { Employment }\end{array}$} & \multicolumn{2}{|c|}{$\begin{array}{c}\text { Non-Farm } \\
\text { Self-Employment }\end{array}$} \\
\hline Household characteristics & Female & Male & Female & Male & Female & Male & Female & Male \\
\hline Age of adults(years) & $\begin{array}{l}0.0067 * \\
(0.0036)\end{array}$ & $\begin{array}{l}0.0031 \\
(0.0038)\end{array}$ & $\begin{array}{l}0.0032 \\
(0.0023)\end{array}$ & $\begin{array}{l}-0.0021 \\
(0.0025)\end{array}$ & $\begin{array}{l}-0.0079 * * \\
(0.0035)\end{array}$ & $\begin{array}{l}0.0146 * * * \\
(0.0038)\end{array}$ & $\begin{array}{l}-0.0116^{* * * *} \\
(0.0032)\end{array}$ & $\begin{array}{l}-0.0058^{*} \\
(0.0032)\end{array}$ \\
\hline Age squared & $\begin{array}{l}-0.1128 * \\
(0.0685)\end{array}$ & $\begin{array}{l}-0.0494 \\
(0.0746)\end{array}$ & $\begin{array}{l}-0.0460 \\
(0.0452)\end{array}$ & $\begin{array}{l}0.0479 \\
(0.0488)\end{array}$ & $\begin{array}{l}0.0913 \\
(0.0657)\end{array}$ & $\begin{array}{l}0.2420 * * * \\
(0.0734)\end{array}$ & $\begin{array}{l}0.1931 * * * \\
(0.0611)\end{array}$ & $\begin{array}{l}0.1033 \\
(0.0632)\end{array}$ \\
\hline Education of adults (years) & $\begin{array}{l}0.0034 \\
(0.0051)\end{array}$ & $\begin{array}{l}0.0113 * * \\
(0.0056)\end{array}$ & $\begin{array}{l}-0.0013 \\
(0.0033)\end{array}$ & $\begin{array}{l}0.0041 \\
(0.0037)\end{array}$ & $\begin{array}{l}-0.0052 \\
(0.0048)\end{array}$ & $\begin{array}{l}-0.0118 * * \\
(0.0053)\end{array}$ & $\begin{array}{l}-0.0006 \\
(0.0044)\end{array}$ & $\begin{array}{l}-0.0057 \\
(0.0050)\end{array}$ \\
\hline Gender of head dummy $($ male $=1)$ & $\begin{array}{l}-0.0269 \\
(0.0367)\end{array}$ & $\begin{array}{l}-0.0302 \\
(0.0486) \\
-\end{array}$ & $\begin{array}{l}-0.0644 * * \\
(0.0257)\end{array}$ & $\begin{array}{l}-0.0525 \\
(0.0359)\end{array}$ & $\begin{array}{l}0.0864 * * * \\
(0.0332) \\
-\end{array}$ & $\begin{array}{l}0.1035 * * \\
(0.0456)\end{array}$ & $\begin{array}{l}0.0185 \\
(0.0314)\end{array}$ & $\begin{array}{l}-0.0797 * * \\
(0.0386)\end{array}$ \\
\hline Age of household head (years) & $\begin{array}{l}-0.0032 * * \\
(0.0014)\end{array}$ & $\begin{array}{l}0.0039 * * * \\
(0.0015)\end{array}$ & $\begin{array}{l}-0.0014 \\
(0.0009)\end{array}$ & $\begin{array}{l}-0.0015 \\
(0.0011)\end{array}$ & $\begin{array}{l}0.0035^{* * * *} \\
(0.0013) \\
-\end{array}$ & $\begin{array}{l}-0.0007 \\
(0.0014)\end{array}$ & $\begin{array}{l}0.0027 * * \\
(0.0011)\end{array}$ & $\begin{array}{l}-0.0003 \\
(0.0012)\end{array}$ \\
\hline Education of household head (years) & $\begin{array}{l}0.0052 \\
(0.0045)\end{array}$ & $\begin{array}{l}-0.0068 \\
(0.0053)\end{array}$ & $\begin{array}{l}0.0085^{* * *} \\
(0.0027)\end{array}$ & $\begin{array}{l}-0.0005 \\
(0.0033)\end{array}$ & $\begin{array}{l}0.0118 * * * \\
(0.0041)\end{array}$ & $\begin{array}{l}-0.0049 \\
(0.0050)\end{array}$ & $\begin{array}{l}-0.0065^{*} \\
(0.0038)\end{array}$ & $\begin{array}{l}0.0067 \\
(0.0047)\end{array}$ \\
\hline $\begin{array}{l}\text { Occupation of Household head } \\
\text { (1=farming; }\end{array}$ & & & & & & & & \\
\hline 0 otherwise) & $\begin{array}{l}0.1773 * * * \\
(0.0373)\end{array}$ & $\begin{array}{l}0.1888 * * * \\
(0.0354)\end{array}$ & $\begin{array}{l}0.1000 * * * \\
(0.0234)\end{array}$ & $\begin{array}{l}0.1043 * * * \\
(0.0223)\end{array}$ & $\begin{array}{l}-0.0694 * * \\
(0.0326)\end{array}$ & $\begin{array}{l}0.1076 * * * \\
(0.0336)\end{array}$ & $\begin{array}{l}-0.2125^{* * *} \\
(0.0291)\end{array}$ & $\begin{array}{l}-0.1826 * * * \\
(0.0292)\end{array}$ \\
\hline Number of children $(0-5)$ years & $\begin{array}{l}-0.0237 \\
(0.0343)\end{array}$ & $\begin{array}{l}-0.0600 * \\
(0.0355)\end{array}$ & $\begin{array}{l}0.0253 \\
(0.0233)\end{array}$ & $\begin{array}{l}0.0025 \\
(0.0235)\end{array}$ & $\begin{array}{l}-0.0623 * * \\
(0.0307)\end{array}$ & $\begin{array}{l}-0.0254 \\
(0.0343)\end{array}$ & $\begin{array}{l}0.0881 * * * \\
(0.0264)\end{array}$ & $\begin{array}{l}0.1216^{* * *} \\
(0.0296)\end{array}$ \\
\hline Number of children (6-14) years & $\begin{array}{l}-0.0054 \\
(0.0149)\end{array}$ & $\begin{array}{l}-0.0124 \\
(0.0148)\end{array}$ & $\begin{array}{l}-0.0098 \\
(0.0095)\end{array}$ & $\begin{array}{l}-0.0076 \\
(0.0104)\end{array}$ & $\begin{array}{l}0.0094 \\
(0.0133)\end{array}$ & $\begin{array}{l}-0.0068 \\
(0.0144)\end{array}$ & $\begin{array}{l}0.0124 \\
(0.0122)\end{array}$ & $\begin{array}{l}0.0039 \\
(0.0129)\end{array}$ \\
\hline Physical and financial assets & & & & & & & & \\
\hline Ln total assets (KSh) & $\begin{array}{l}0.0456 * * * \\
(0.0140)\end{array}$ & $\begin{array}{l}0.0565 * * * \\
(0.0133)\end{array}$ & $\begin{array}{l}-0.0133 \\
(0.0086)\end{array}$ & $\begin{array}{l}-0.0032 \\
(0.0082)\end{array}$ & $\begin{array}{l}-0.0164 \\
(0.0123)\end{array}$ & $\begin{array}{l}-0.0137 \\
(0.0124)\end{array}$ & $\begin{array}{l}0.0362 * * * \\
(0.0114)\end{array}$ & $\begin{array}{l}0.0222 * * \\
(0.0109)\end{array}$ \\
\hline
\end{tabular}




\begin{tabular}{|c|c|c|c|c|c|c|c|c|}
\hline \multirow{2}{*}{ Non-labor income (yes=1) } & \multirow{3}{*}{$\begin{array}{l}0.0918 * * * \\
(0.0318)\end{array}$} & \multirow{3}{*}{$\begin{array}{l}0.0882 * * * \\
(0.0331)\end{array}$} & \multirow{3}{*}{$\begin{array}{l}0.0193 \\
(0.0205)\end{array}$} & \multirow{3}{*}{$\begin{array}{l}0.0097 \\
(0.0216)\end{array}$} & \multirow{3}{*}{$\begin{array}{l}- \\
0.1966 * * * \\
(0.0304)\end{array}$} & \multirow{3}{*}{$\begin{array}{l}- \\
0.1879 * * * \\
(0.0331)\end{array}$} & \multirow{3}{*}{$\begin{array}{l}-0.1016^{* * * *} \\
(0.0281)\end{array}$} & \multirow{3}{*}{$\begin{array}{l}-0.1641 * * * \\
(0.0317)\end{array}$} \\
\hline & & & & & & & & \\
\hline & & & & & & & & \\
\hline \multirow[t]{2}{*}{ Total land owned (acre) } & -0.0062 & 0.0015 & -0.0054 & 0.0008 & -0.0151 & -0.0041 & 0.0072 & 0.0043 \\
\hline & $(0.0077)$ & $(0.0091)$ & $(0.0041)$ & $(0.0060)$ & $(0.0092)$ & $(0.0080)$ & $(0.0055)$ & $(0.0062)$ \\
\hline \multirow[t]{2}{*}{ Owned livestock size (TLU) } & 0.0232 & -0.0088 & 0.0269 & $0.0495 * *$ & -0.0383 & -0.0555 & -0.0077 & -0.0039 \\
\hline & $(0.0399)$ & $(0.0386)$ & $(0.0219)$ & $(0.0241)$ & $(0.0406)$ & $(0.0445)$ & $(0.0349)$ & $(0.0350)$ \\
\hline \multirow[t]{2}{*}{ Credit constrained $($ yes $=1)$} & -0.0351 & -0.0412 & $0.0942 * * *$ & $0.1529 * * *$ & 0.0277 & 0.0351 & $0.0613 * *$ & 0.0112 \\
\hline & $(0.0341)$ & $(0.0349)$ & $(0.0280)$ & $(0.0360)$ & $(0.0300)$ & $(0.0329)$ & $(0.0289)$ & $(0.0318)$ \\
\hline $\begin{array}{l}\text { Social Capital and Community } \\
\text { variable }\end{array}$ & & & & & & & & \\
\hline \multirow[t]{2}{*}{ Group membership (yes $=1$ ) } & 0.0476 & $0.0638 *$ & $0.0363 *$ & $0.0448 * *$ & $0.0705 * *$ & $0.0613 *$ & 0.0268 & -0.0078 \\
\hline & $(0.0336)$ & $(0.0336)$ & $(0.0210)$ & $(0.0208)$ & $(0.0327)$ & $(0.0344)$ & $(0.0311)$ & $(0.0313)$ \\
\hline Distance to market $(\mathrm{km})$ & $\begin{array}{l}0.0049 * * * \\
(0.0016)\end{array}$ & $\begin{array}{l}0.0039 * * \\
(0.0016)\end{array}$ & $\begin{array}{l}0.0034 * * * \\
(0.0011) \\
\end{array}$ & $\begin{array}{l}0.0029 * * * \\
(0.0011)\end{array}$ & $\begin{array}{l}0.0046 * * * \\
(0.0019)\end{array}$ & $\begin{array}{l}-0.0015 \\
(0.0015) \\
\end{array}$ & $\begin{array}{l}0.0005 \\
(0.0013) \\
\end{array}$ & $\begin{array}{l}-0.0001 \\
(0.0013) \\
\end{array}$ \\
\hline \multirow[t]{2}{*}{ Constant } & 0.5516 & -0.4797 & $2.9072 *$ & -0.3891 & 0.1892 & $-3.0870 * *$ & $-5.4384 * * *$ & -2.4991 \\
\hline & $(1.1582)$ & $(1.3450)$ & $(1.5597)$ & $(1.8190)$ & $(1.2923)$ & $(1.4439)$ & $(1.3119)$ & $(1.4039)$ \\
\hline Wald chic2(16) & 71.02 & 53.41 & 140.3 & 147.39 & 68.91 & 83.84 & 46.71 & 49.15 \\
\hline Prob>chi2 & 0.0000 & 0.0000 & 0.0000 & 0.0000 & 0.0000 & 0.0000 & 0.0001 & 0.0000 \\
\hline Log pseudolikelihood & -158.948 & -140.654 & -161.147 & -157.665 & -449.893 & -482.742 & -439.248 & -442.837 \\
\hline Observations & 1,109 & 1,086 & 1,109 & 1,086 & 1,086 & 1,109 & 1,109 & 1,086 \\
\hline
\end{tabular}


The result on household assets and financial endowment against male and female participation showed similar patterns in both groups. However, although both male and female labor supply in avocado production increased with asset level and non-farm income, the chances of male participation were higher than female participation under similar conditions. This points to marginalization of women in labour market participation. On the other hand, the likelihood of female participation becomes much higher than for their male counterparts as non-labor income increase. Similarly, the probability of female engaging in non-farm self-employment was 0.02 times higher than that of male participation. The chances of supplying less labor with increase in nonfarm income were 0.06 times higher for males than females. It is likely that with non-farm income, women are able to solicit for caregivers for their children and thus free up time to work on their farms.

Non-labor income lowered the probability of participation in wage employment by 18.8 percent in males and 19.7 percent in females. Total livestock units owned had a positive correlation with male participation in other crop farming but this association was not significant for female farmers. Furthermore, the probability of male participation in other crop production when facing credit constraints was 5.9 percent higher than for female participation under similar circumstances. There was a positive correlation between credit constraints and female involvement in non-farm selfemployment but the effect was not significant for males. This could be explained by the fact that credit constrained women opt to look for non-farm employment for a livelihood. Unlike their male counterparts, females were likely to spend more time in avocado production with increase in non-labor income and less time when facing credit constraints. This could probably be that non-labor income, relaxes credit constraints that women farmers may be faced with and thus enable them to spend more time in avocado production. Whereas, credit constraint may induce them to search for other non-farm opportunities thereby reducing time spent in avocado production. The overall results imply that gender differences in economic assets and opportunities influences gender differences in labor allocation decisions which also reinforces gender differences in opportunities (Ilahi, 2000). 
Table 3: Average Partial Effects of Parameter Estimates of Double Hurdle Model for Intensity of Labor Allocation

\begin{tabular}{|c|c|c|c|c|c|c|c|c|}
\hline \multirow{3}{*}{$\frac{\text { Variable }}{\text { Household characteristics }}$} & \multicolumn{8}{|c|}{ Unconditional Marginal Effect } \\
\hline & Avocado & roduction & \multicolumn{2}{|c|}{$\begin{array}{c}\text { Other } \\
\text { Farming Activities }\end{array}$} & \multicolumn{2}{|c|}{$\begin{array}{c}\text { Wage } \\
\text { Employment }\end{array}$} & \multicolumn{2}{|c|}{$\begin{array}{l}\text { Non-Farm Self- } \\
\text { Employment }\end{array}$} \\
\hline & Female & Male & Female & Male & Female & Male & Female & Male \\
\hline Age of adults (years) & $\begin{array}{l}0.0013 \\
(0.0011)\end{array}$ & $\begin{array}{l}0.0018 \\
(0.0013)\end{array}$ & $\begin{array}{l}0.0040^{* *} \\
(0.0017)\end{array}$ & $\begin{array}{l}0.0065 * * * \\
(0.0020)\end{array}$ & $\begin{array}{l}-0.0026 \\
(0.0019)\end{array}$ & $\begin{array}{l}0.0073 * * * \\
(0.0020)\end{array}$ & $\begin{array}{l}0.0052 * * * \\
(0.0019)\end{array}$ & $\begin{array}{l}-0.0026 \\
(0.0018)\end{array}$ \\
\hline Age squared & $\begin{array}{l}-0.0307 \\
(0.0219)\end{array}$ & $\begin{array}{l}-0.0312 \\
(0.0249)\end{array}$ & $\begin{array}{l}-0.0544 \\
(0.0334)\end{array}$ & $\begin{array}{l}0.1205 * * * \\
(0.0403)\end{array}$ & $\begin{array}{l}0.0228 \\
(0.0353)\end{array}$ & $\begin{array}{l}0.1240 * * * \\
(0.0393)\end{array}$ & $\begin{array}{l}0.0926 * * * \\
(0.0354)\end{array}$ & $\begin{array}{l}0.0502 \\
(0.0355)\end{array}$ \\
\hline $\begin{array}{l}\text { Education of adult male/female } \\
\text { (years) }\end{array}$ & $\begin{array}{l}-0.0010 \\
(0.0016)\end{array}$ & $\begin{array}{l}0.0010 \\
(0.0018)\end{array}$ & $\begin{array}{l}0.0001 \\
(0.0026)\end{array}$ & $\begin{array}{l}0.0073 * * \\
(0.0031)\end{array}$ & $\begin{array}{l}-0.0023 \\
(0.0026)\end{array}$ & $\begin{array}{l}-0.0068 * * \\
(0.0028)\end{array}$ & $\begin{array}{l}0.0008 \\
(0.0025)\end{array}$ & $\begin{array}{l}-0.0028 \\
(0.0028)\end{array}$ \\
\hline $\begin{array}{l}\text { Gender } \\
(\mathrm{male}=1)\end{array}$ of head dummy & $-0.0259 * *$ & -0.0008 & $-0.0349 *$ & -0.0003 & $0.0345^{* *}$ & $0.0453 *$ & 0.0021 & $0.0597 * * *$ \\
\hline Age of household head (years) & $\begin{array}{l}(0.0117) \\
-0.0001 \\
(0.0005)\end{array}$ & $\begin{array}{l}(0.0154) \\
-0.0009 * \\
(0.0005)\end{array}$ & $\begin{array}{l}(0.0184) \\
-0.0004 \\
(0.0007)\end{array}$ & $\begin{array}{l}(0.0272) \\
-0.0007 \\
(0.0008)\end{array}$ & $\begin{array}{l}(0.0176) \\
-0.0016^{* *} \\
(0.0007) \\
-\end{array}$ & $\begin{array}{l}(0.0238) \\
0.0004 \\
(0.0008)\end{array}$ & $\begin{array}{l}(0.0179) \\
0.0017 * * \\
(0.0007)\end{array}$ & $\begin{array}{l}(0.0212) \\
-0.0001 \\
(0.0007)\end{array}$ \\
\hline Education of households (years) & $\begin{array}{l}0.0031 * * \\
(0.0015)\end{array}$ & $\begin{array}{l}0.0003 \\
(0.0016)\end{array}$ & $\begin{array}{l}0.0089 * * * \\
(0.0023)\end{array}$ & $\begin{array}{l}-0.0013 \\
0.0028\end{array}$ & $\begin{array}{l}0.0071 * * * \\
(0.0022)\end{array}$ & $\begin{array}{l}-0.0028 \\
(0.0028) \\
-\end{array}$ & $\begin{array}{l}-0.0037 * \\
(0.0022) \\
-\end{array}$ & $\begin{array}{l}0.0041 \\
(0.0027) \\
-\end{array}$ \\
\hline Occupation of Household head & $\begin{array}{l}0.0673 * * * \\
(0.0145)\end{array}$ & $\begin{array}{l}0.0792 * * * \\
(0.0134) \\
-\end{array}$ & $\begin{array}{l}0.1584 * * * \\
(0.0262)\end{array}$ & $\begin{array}{l}0.1427 * * * \\
(0.0251)\end{array}$ & $\begin{array}{l}-0.0393 * * \\
(0.0173)\end{array}$ & $\begin{array}{l}0.0537 * * * \\
(0.0177)\end{array}$ & $\begin{array}{l}0.1233 * * * \\
(0.0163)\end{array}$ & $\begin{array}{l}0.1030 * * * \\
(0.0163)\end{array}$ \\
\hline Proportion of children $(0-5)$ years & $\begin{array}{l}0.0398 * * * \\
(0.0133)\end{array}$ & $\begin{array}{l}0.0363 * * * \\
(0.0133)\end{array}$ & $\begin{array}{l}-0.0079 \\
(0.0198)\end{array}$ & $\begin{array}{l}-0.0424 * \\
(0.0244)\end{array}$ & $\begin{array}{l}-0.0305^{*} \\
(0.0173)\end{array}$ & $\begin{array}{l}-0.0180 \\
(0.0198)\end{array}$ & $\begin{array}{l}0.0496 * * * \\
(0.0138)\end{array}$ & $\begin{array}{l}0.0653 * * * \\
(0.0152)\end{array}$ \\
\hline Proportion of children (6-14) years & $\begin{array}{l}-0.0086^{*} \\
(0.0049)\end{array}$ & $\begin{array}{l}-0.0105 * * \\
(0.0054)\end{array}$ & $\begin{array}{l}-0.0149 * \\
(0.0085)\end{array}$ & $\begin{array}{l}-0.0057 \\
(0.0085)\end{array}$ & $\begin{array}{l}0.0123 * \\
(0.0070)\end{array}$ & $\begin{array}{l}0.0081 \\
(0.0075)\end{array}$ & $\begin{array}{l}0.0074 \\
(0.0071)\end{array}$ & $\begin{array}{l}0.0032 \\
(0.0076)\end{array}$ \\
\hline Physical and financial assets & & & & & & & & \\
\hline ln total assets (Ksh) & $0.0154 * * *$ & $0.0144 * * *$ & -0.0098 & -0.0035 & $-0.0174 * *$ & $-0.0120 *$ & $0.0191 * * *$ & 0.0093 \\
\hline
\end{tabular}




\begin{tabular}{|c|c|c|c|c|c|c|c|c|}
\hline & $(0.0043)$ & $(0.0040)$ & $(0.0070)$ & $(0.0069)$ & $(0.0072)$ & $(0.0070)$ & $(0.0068)$ & $(0.0065)$ \\
\hline \multirow[t]{2}{*}{ Non-farm income (yes=1) } & $0.0201 * *$ & 0.0131 & $0.0922 * * *$ & $0.0956 * * *$ & $0.0837 * * *$ & $0.0622 * * *$ & $0.0472 * * *$ & $0.0825 * * *$ \\
\hline & $(0.0099)$ & $(0.0104)$ & $(0.0145)$ & $(0.0151)$ & $(0.0168)$ & $(0.0179)$ & $(0.0159)$ & $(0.0182)$ \\
\hline \multirow[t]{2}{*}{ Total land owned (acre) } & 0.0028 & $0.0057 * *$ & -0.0003 & -0.0027 & -0.0063 & -0.0041 & 0.0025 & 0.0009 \\
\hline & $(0.0023)$ & $(0.0026)$ & $(0.0036)$ & $(0.0042)$ & $(0.0054)$ & $(0.0058)$ & $(0.0033)$ & $(0.0039)$ \\
\hline \multirow[t]{2}{*}{ Owned livestock size } & $-0.0326 * *$ & $0.0428 * * *$ & 0.0037 & 0.0255 & -0.0081 & -0.0152 & 0.0104 & 0.0102 \\
\hline & $(0.0169)$ & $(0.0167)$ & $(0.0207)$ & $(0.0202)$ & $(0.0222)$ & $(0.0244)$ & $(0.0165)$ & $(0.0161)$ \\
\hline \multirow[t]{2}{*}{ Credit Constrained (yes=1) } & $0.0383 * * *$ & $-0.0198 *$ & 0.0187 & $0.0417 * *$ & 0.0048 & 0.0167 & $0.0315^{* *}$ & -0.0003 \\
\hline & $(0.0118)$ & $(0.0118)$ & $(0.0190)$ & $(0.0214)$ & $(0.0159)$ & $(0.0170)$ & $(0.0160)$ & $(0.0179)$ \\
\hline \multicolumn{9}{|l|}{ Social Capital } \\
\hline \multirow[t]{2}{*}{ Group membership (yes $=1$ ) } & 0.0083 & 0.0075 & -0.0059 & 0.0157 & 0.0178 & 0.0022 & -0.0118 & $-0.0343^{* *}$ \\
\hline & $(0.0109)$ & $(0.0111)$ & $(0.0169)$ & $(0.0175)$ & $(0.0178)$ & $(0.0181)$ & $(0.0173)$ & $(0.0172)$ \\
\hline \multirow[t]{2}{*}{ Distance to market $(\mathrm{km})$} & $0.0012 * * *$ & 0.0005 & $0.0015^{* *}$ & 0.0003 & -0.0017 & 0.0003 & -0.0002 & 0.0000 \\
\hline & $(0.0005)$ & $(0.0005)$ & $(0.0007)$ & $(0.0008)$ & $(0.0011)$ & $(0.0008)$ & $(0.0008)$ & $(0.0008)$ \\
\hline \multirow[t]{2}{*}{ Constant } & 0.0091 & 0.2727 & 0.4121 & $1.2466 * * *$ & $1.2554 * * *$ & 0.4421 & $0.6815^{* *}$ & $0.7714 * *$ \\
\hline & $(0.3141)$ & $(0.3561)$ & $(0.2659)$ & $(0.3473)$ & $(0.2598)$ & $(0.3739)$ & $(0.3056)$ & $(0.3915)$ \\
\hline Wald chic2(16) & 71.02 & 53.41 & 140.30 & 147.39 & 68.91 & 83.84 & 46.71 & 49.15 \\
\hline Prob>chi2 & 0.0000 & 0.0000 & 0.0000 & 0.0000 & 0.0000 & 0.0000 & 0.0001 & 0.0000 \\
\hline \multirow[t]{2}{*}{ Log pseudolikelihood } & -158.948 & -140.654 & -161.147 & -157.665 & -449.893 & -482.742 & -439.248 & -442.837 \\
\hline & - & - & - & - & - & - & - & - \\
\hline \multirow{2}{*}{ lnsigma } & $\begin{array}{l}1.57 / 79^{*}+.6 \\
(0.0520)\end{array}$ & $(0.0524)$ & $\begin{array}{l}1.3 / 47 \times 1 \times \\
(0.0287)\end{array}$ & $\begin{array}{l}1.3367 * * * \\
(0.0298)\end{array}$ & $1.7653^{* * *}$ & $1.7165 * * *$ & $\begin{array}{l}1.7669^{* \cdots *} \\
(0.0453)\end{array}$ & $(0.0431)$ \\
\hline & 0.2064 & 0.2033 & 0.2529 & $\begin{array}{l}(0.0290) \\
0.2627\end{array}$ & $\begin{array}{l}(0.0421) \\
0.1711)\end{array}$ & $(0.0453)$ & $\begin{array}{l}(0.0453) \\
0.1709\end{array}$ & $\begin{array}{l}(0.0431) \\
0.1796\end{array}$ \\
\hline Sigma & $(0.0107)$ & $(0.0107)$ & $(0.0073)$ & $(0.0078)$ & $\begin{array}{l}0.1711 \\
(0.0072)\end{array}$ & $\begin{array}{l}0.1797 \\
(0.0081)\end{array}$ & $(0.0077)$ & $(0.0077)$ \\
\hline Observations & 1,109 & 1,086 & 1,109 & 1,086 & 1,086 & 1,109 & 1,109 & 1,086 \\
\hline
\end{tabular}

Robust standard errors in parenthesis, ${ }^{*}, * *, * *$ Significant at $10 \%, 5 \%$ and $1 \%$ 


\subsection{The Role of Avocado Contract Farming on Gender Labor Allocation}

This analysis in this section focused on the extent and influence of contract farming on possible changes in gender roles in avocado production activities regarding participation and the amount of time spent on land preparation, weeding, harvesting and marketing. The analyses also focused on identifying factors that constraint or improve participation and time allocation in the various tasks. The Tobit model was used for the analysis since the the null hypothesis of the Tobit nested in the double hurdle model was not rejected by the likelihood test. The likelihood and F-statistics indicate that our model fits the data well. The basic hypothesis is that avocado contract farming has changed traditional women's role in avocado production activities.

From the result in Table 4, contract farming increased both male and female participation and time use in avocado farming activities. Notable differences were however observed between the two groups in their relative roles in land preparation, weeding and marketing. In particular, the result revealed that the contribution of males is much higher in land preparation, harvesting and marketing. The probability of male participation and time use in land preparation, weeding harvesting and marketing activities was 2.05, 0.11, 0.85 and 1.11 percentage points higher than for their female counterparts. Women on the other hand were seen to have a major responsibility in weeding, with their participation and time use increasing by 0.47 percentage points.

While there seems to be clear gender roles and responsibilities in avocado production activities, with contract farming the probability of female participation and time use in land preparation and harvesting was seen to increase by 0.02 and 0.15 percentage points, However, female participation in marketing was observed to diminish by 0.17 percentage points. The overall result suggests that there is a gradual shift in traditional gender role in avocado commercialization through contract farming. The limited participation of women in marketing also suggests that as avocado production becomes more commercialized women farmers tend to be left out of the marketing chain. This finding highlights earlier observation by Boserup's (1970) and some more recent studies (Fischer and Qaim, 2012; Oduol et al., 2017; Dolan, 2001). Education was found to be a key correlate of labour allocation decision. Males, who had more years of education had a greater probability of participating in avocado marketing compared to their female counterparts. This corroborates with finding in Mwambi et al., (2013), who found education to be a significant predictor of contract farming. Larger household size, farming as the main occupation and the number of Hass trees and non-labor income also increased the probability of participation and time use for both males and females in avocado production activities. The presence of children aged five and below lowered female participation and time use in almost all activities. This 
suggests that women with young children may have to tradeoff work for being stay home moms. An interesting finding was the positive and significant coefficient associated with voting for leaders in avocado group for females in all activities and the insignificant effects for males. This could be explained by the fact that for females, bringing out their voices through voting for avocado group leaders serve as a motivation for more participation and time use in avocado production. For male farmers, voting for themselves may not be of much significance to their tasks as they are the ones most often elected. Credit constraints had a negative and significant effect on both male and female in avocado production activities, implying that credit constraint serve as a barrier to avocado production. Participation in avocado agronomy and marketing training increased the probability of male participation and time use in land preparation, harvesting and marketing. The positive link between training in avocado agronomy and increased participation and time use by males in avocado production activities, suggests that farmer training can be an effective approach of increasing the marginal input and productivity of avocado farmers. 
Table 4: Average Partial Effects of Tobit Model for Female and Male Avocado Contract Labor Allocation Unconditional expectations

\begin{tabular}{|c|c|c|c|c|c|c|c|c|}
\hline \multirow[t]{2}{*}{ Variable } & \multicolumn{2}{|c|}{ Land Preparation } & \multicolumn{2}{|c|}{ Weeding } & \multicolumn{2}{|c|}{ Harvesting } & \multicolumn{2}{|c|}{ Marketing } \\
\hline & Female & Male & Female & Male & Female & Male & Female & Male \\
\hline Contract farming $($ yes $=1)$ & $\begin{array}{l}0.016 * \\
(1.621) \\
-\end{array}$ & $\begin{array}{l}2.054 * * \\
(1.675)\end{array}$ & $\begin{array}{l}0.472 * * \\
(1.383)\end{array}$ & $\begin{array}{l}0.114 * \\
(0.832)\end{array}$ & $\begin{array}{l}0.150 * * \\
(1.074) \\
-\end{array}$ & $\begin{array}{l}0.854 * * \\
(1.092)\end{array}$ & $\begin{array}{l}-0.174 \\
(0.441)\end{array}$ & $\begin{array}{l}1.058 * * \\
* \\
(0.520)\end{array}$ \\
\hline Age of adults (years) & $\begin{array}{l}0.101 * * * \\
(0.036)\end{array}$ & $\begin{array}{l}0.014 \\
(0.054)\end{array}$ & $\begin{array}{l}-0.086 * * \\
(0.036)\end{array}$ & $\begin{array}{l}0.015 \\
(0.025)\end{array}$ & $\begin{array}{l}0.105 * * * \\
(0.037)\end{array}$ & $\begin{array}{l}-0.001 \\
(0.036)\end{array}$ & $\begin{array}{l}0.024 \\
(0.016)\end{array}$ & $\begin{array}{l}-0.015 \\
(0.017)\end{array}$ \\
\hline Education of adults (years) & $\begin{array}{l}-0.061 \\
(0.185)\end{array}$ & $\begin{array}{l}0.123 \\
(0.185) \\
6.333 * *\end{array}$ & $\begin{array}{l}-0.006 \\
(0.177)\end{array}$ & $\begin{array}{l}0.271 \\
(0.109)\end{array}$ & $\begin{array}{l}0.077 \\
(0.176)\end{array}$ & $\begin{array}{l}0.226 \\
(0.153) \\
8.170 * *\end{array}$ & $\begin{array}{l}0.097 \\
(0.071)\end{array}$ & $\begin{array}{l}0.015 * * \\
(0.068) \\
3.052 * *\end{array}$ \\
\hline Main occupation (Farming $=1 ; 0$ otherwise) & $\begin{array}{l}3.834 * * * \\
(1.404)\end{array}$ & $\begin{array}{l}* \\
(1.417)\end{array}$ & $\begin{array}{l}5.353 * * * \\
(1.332)\end{array}$ & $\begin{array}{l}1.351 * \\
(0.810)\end{array}$ & $\begin{array}{l}4.601 * * * \\
(1.224)\end{array}$ & $\begin{array}{l}* \\
(1.187) \\
-\end{array}$ & $\begin{array}{l}0.149 \\
(0.546)\end{array}$ & $\begin{array}{l}* \\
(0.568)\end{array}$ \\
\hline Marital status (Married=1) & $\begin{array}{l}2.039 * \\
(1.138)\end{array}$ & $\begin{array}{l}2.172 \\
(2.384) \\
1.175^{* *}\end{array}$ & $\begin{array}{l}1.472 \\
(1.005)\end{array}$ & $\begin{array}{l}-0.657 \\
(1.025)\end{array}$ & $\begin{array}{l}-0.264 \\
(0.976)\end{array}$ & $\begin{array}{l}2.901 * * \\
(1.384)\end{array}$ & $\begin{array}{l}-0.384 \\
(0.398)\end{array}$ & $\begin{array}{l}-0.887 \\
(0.652)\end{array}$ \\
\hline Household size (no. of persons) & $\begin{array}{l}0.831 * * * \\
(0.301) \\
-\end{array}$ & $\begin{array}{l}* \\
(0.329)\end{array}$ & $\begin{array}{l}0.775 * * \\
(0.312) \\
-\end{array}$ & $\begin{array}{l}0.439 * * \\
(0.194)\end{array}$ & $\begin{array}{l}0.280 \\
(0.234)\end{array}$ & $\begin{array}{l}0.541 * * \\
(0.282)\end{array}$ & $\begin{array}{l}0.052 \\
(0.107) \\
-\end{array}$ & $\begin{array}{l}0.113 \\
(0.119) \\
0.462 * *\end{array}$ \\
\hline Number of children $(0-5)$ years & $\begin{array}{l}0.336 * * * \\
(0.338)\end{array}$ & $\begin{array}{l}-0.038 \\
(0.397)\end{array}$ & $\begin{array}{l}0.337 * * * \\
(0.322)\end{array}$ & $\begin{array}{l}0.058 \\
(0.251)\end{array}$ & $\begin{array}{l}-0.113 \\
(0.273)\end{array}$ & $\begin{array}{l}0.892 * * \\
(0.304)\end{array}$ & $\begin{array}{l}0.364 * * * \\
(0.133)\end{array}$ & $\begin{array}{l}* \\
(0.155) \\
0.240 * *\end{array}$ \\
\hline No of mature Hass trees & $\begin{array}{l}0.050 \\
(0.037)\end{array}$ & $\begin{array}{l}0.080 * * \\
(0.038)\end{array}$ & $\begin{array}{l}0.077 * * \\
(0.032)\end{array}$ & $\begin{array}{l}-0.029 \\
(0.029)\end{array}$ & $\begin{array}{l}0.073 * * * \\
(0.026)\end{array}$ & $\begin{array}{l}0.325 * * \\
(0.025)\end{array}$ & $\begin{array}{l}0.030 * * \\
(0.014)\end{array}$ & $\begin{array}{l}* \\
(0.111)\end{array}$ \\
\hline No of mature Fuerte trees & $\begin{array}{l}0.147 \\
(0.164)\end{array}$ & $\begin{array}{l}0.061 \\
(0.038) \\
0.604 * *\end{array}$ & $\begin{array}{l}0.075 \\
(0.136)\end{array}$ & $\begin{array}{l}0.049 \\
(0.103)\end{array}$ & $\begin{array}{l}-0.114 \\
(0.106)\end{array}$ & $\begin{array}{l}0.002 \\
(0.085)\end{array}$ & $\begin{array}{l}0.080 \\
(0.069)\end{array}$ & $\begin{array}{l}0.042 \\
(0.042) \\
0.199 * *\end{array}$ \\
\hline Non-labor income (Ksh) & $\begin{array}{l}0.135 \\
(0.222) \\
-\end{array}$ & $\begin{array}{l}* \\
(0.161) \\
-\end{array}$ & $\begin{array}{l}0.205 \\
(0.169)\end{array}$ & $\begin{array}{l}-0.572 \\
(0.087) \\
-\end{array}$ & $\begin{array}{l}-0.063 \\
(0.139)\end{array}$ & $\begin{array}{l}0.136 \\
(0.130)\end{array}$ & $\begin{array}{l}0.166^{* * * *} \\
(0.062)\end{array}$ & $\begin{array}{l}* \\
(0.066) \\
-\end{array}$ \\
\hline credit constraint (yes $=1$ ) & $2.948 * * *$ & $2.544 * *$ & $-0.833 * *$ & $3.616 * * *$ & -0.341 & $-1.670^{*}$ & -0.454 & $1.222 * *$ \\
\hline
\end{tabular}




\begin{tabular}{|c|c|c|c|c|c|c|c|c|}
\hline & $(0.918)$ & (1.168) & $(0.953)$ & $(0.892)$ & $(0.914)$ & $\begin{array}{l}(1.010) \\
0.136 * *\end{array}$ & $(0.473)$ & $(0.510)$ \\
\hline $\begin{array}{l}\text { Number of avocado group meetings } \\
\text { attended in a } 12 \text { months }\end{array}$ & $\begin{array}{l}0.159 * * \\
(0.043)\end{array}$ & $\begin{array}{l}0.085 * * \\
(0.048)\end{array}$ & $\begin{array}{l}0.214 * * * \\
(0.049)\end{array}$ & $\begin{array}{l}-0.029 \\
(0.034)\end{array}$ & $\begin{array}{l}0.108 * * * \\
(0.049)\end{array}$ & $\begin{array}{l}* \\
(0.038)\end{array}$ & $\begin{array}{l}0.013 \\
(0.016)\end{array}$ & $\begin{array}{l}0.047 * * \\
(0.021)\end{array}$ \\
\hline $\begin{array}{l}\text { Voted in avocado group elections } \\
(\text { yes }=1)\end{array}$ & $\begin{array}{l}4.013 * * * \\
(0.978)\end{array}$ & $\begin{array}{l}1.920 \\
(1.180)\end{array}$ & $\begin{array}{l}1.949 * * \\
(1.000)\end{array}$ & $\begin{array}{l}2.080 \\
(0.734)\end{array}$ & $\begin{array}{l}1.517 * * \\
(1.046)\end{array}$ & $\begin{array}{l}1.224 \\
(0.907)\end{array}$ & $\begin{array}{l}1.120 * * * \\
(0.376)\end{array}$ & $\begin{array}{l}0.340 \\
(0.388) \\
1.344 * *\end{array}$ \\
\hline $\begin{array}{l}\text { Attended training on avocado agronomy } \\
\& \text { marketing }(\text { yes }=1)\end{array}$ & $\begin{array}{l}0.591 \\
(1.455)\end{array}$ & $\begin{array}{l}0.196 * * \\
(1.559)\end{array}$ & $\begin{array}{l}0.214 \\
(0.049)\end{array}$ & $\begin{array}{l}0.029 \\
(0.034)\end{array}$ & $\begin{array}{l}0.908 \\
(0.993)\end{array}$ & $\begin{array}{l}0.772 * * \\
(0.952)\end{array}$ & $\begin{array}{l}0.297 \\
(0.412)\end{array}$ & (0.472) \\
\hline $\begin{array}{l}\text { [Female F( 14, 1088) ] [Male F( 14, } \\
\text { 1094)] }\end{array}$ & 5.51 & 5.02 & 5.05 & 5.14 & 3.74 & 4.85 & 2.92 & 4.32 \\
\hline Prob $>$ F & 0.000 & 0.000 & 0.000 & 0.000 & 0.000 & $\begin{array}{l}0.000 \\
-\end{array}$ & 0.000 & $\begin{array}{l}0.000 \\
-\end{array}$ \\
\hline Log pseudolikelihood & -4590.16 & -461.80 & -4630.23 & -2500.81 & -4606.14 & 4079.78 & -2759.35 & 2736.87 \\
\hline Observations & 1,078 & 1,084 & 1,078 & 1,084 & 1,078 & 1,084 & 1,078 & 1,084 \\
\hline
\end{tabular}

Robust standard errors in parenthesis, *,**, *** Significant at 10\%, 5\% and 1\% 


\section{Conclusion}

This study empirically analyzed factors that influence gender patterns in labor allocation to avocado production under contract and non-contract scenarios and other economic activities using cross sectional data from Murang'a County, Kenya. Several findings emerged from the double hurdle and Tobit estimations that have significant implications for the understanding of gendered patterns in labor allocation and time use in avocado farming and other activities.

Result showed that education boosts male participation in avocado production. This implies that with modernization of agricultural value chains, education is an imperative asset in avocado contract farming. Unlike males, the presence of young children in the household and credit constraint had a more disabling effect on female involvement and time use in avocado production and wage employment. The implication is that credit-constrained females may be left out of the export market and from the benefits of a sector with potential for growth. Household asset endowment and non-labor income were important correlates that provided incentive and capacity for females to undertaking avocado production and non-farm self-employment. Time substitution by males and females was observed as a complementarity between avocado production and other economic activities.

Extending the analysis to the role of gender in avocado contract farming, we found that with contract farming and thus avocado commercialization, women are now involved in avocado production activities that were traditionally done by men. However, the limited participation of women farmers in marketing is an indication that women are not well integrated in all aspects of avocado production chain. Training played an important role in male task performance.

The positive correlation between avocado production and male education as well as the intensity of time spent by both gender in avocado production suggest that avocado production presents a viable employment opportunity for rural communities; thus policy makers should promote smallholder avocado production by providing incentives that will enable women and youths to produce avocado. This will ensure consistent supply of avocados to meet market demand and may also deal with gender disparity in marketing. The study also recommends that the state department of gender affairs should stimulate positive discussion around greater collaboration and equity in roles and responsibilities within the household. Such discussions may provide suggestions as to how women farmers can fully participate in productive activities even when there are young children in the household to care. It would also provide a forum for women to identify their production constraints and possible strategies on way forward. The limited participation 
of women farmers in avocado production due to credit constraints suggests the need for policies that encourage the growth of both informal and formal credit institutions in rural areas that target the agricultural sector. Collateral requirements and interest rates can also be negotiated to ensure flexibility for women to access credit.

The study findings provide important evidence that could enhance gender equitable policies and strategies in avocado production. This paper contributes to literature in two ways. First, the study provides quantifiable evidence from Kenya of gender patterns in labor allocation to avocado production, other crop farming, wage and non-farm self-employment using a two tier estimation procedure of participation and intensity of time use. The analysis further assessed the role of contract farming on gendered labor allocation in all avocado production activities. The analysis was done separately for males and females

In conclusion, while this study makes important contribution to literature by providing empirical evidence of factors that constraint or facilitate gendered labor allocation behavior in avocado production and other economic activities, domestic activities such as fetching water, cooking, cleaning and other household chores could also affect household labor allocation patterns. This study could not capture their effect due to data limitations. Future studies should investigate how such activities affect male and female participation and time use in avocado production. Such analysis could provide relevant information in addressing challenges that limit participation in production.

\section{Acknowledgements}

The authors would like to acknowledge financial support from the productive employment in segmented markets of fresh produce (PRESM) project, which was part of the research agenda of the Knowledge Platform on Inclusive Development Policies funded by the Ministry of Foreign Affairs through the Dutch Science Foundation NWO-WOTRO. The project was implemented and led by Partnership for Economic Policy (PEP) in collaboration with the VU-University of Amsterdam and University Amsterdam/Amsterdam Institute for Global Health and Development (AIGHD)-University of Amsterdam, University of Nairobi, Fresh Produce and Exporters Association of Kenya (FPEAK) and Grupo de Análisis para el Desarrollo (GRADE), in collaboration with PRIME-ITC coordinated by LEI Wageningen UR.

\section{References:}

1. Babatunde, R.O. (2015). On-Farm and Off-Farm Works: Complement or Substitute? Evidence from Nigeria. Maastricht School of 
Management (MSM) Working Paper No. 2015/02. (Maastricht School of Management, Maastricht, the Netherlands).

2. Cragg, J. (1971). Some Statistical Models for Limited Dependent Variables with Application to the Demand for Durable Goods. Econometrica, 39(5), 829-844. doi:10.2307/1909582

3. Dolan, C., and Sutherland, K. (2002) Gender and Employment in the Kenya Horticulture Value Chain. Globalisation and Poverty Discussion Paper, 8.

4. Eerdewijk, A. and Danielsen, K. (2015) Gender Matters in Farm Power Available online: https://www.researchgate.net/publication/282976045_Gender_Matter s_in_Farm_Power (accessed on 15 November 2018).

5. Fafchamps, M., \& Quisumbing, A. (2003). Social Roles, Human Capital, and the Intrahousehold Division of Labor: Evidence from Pakistan. Oxford Economic Papers, 55(1), 36-80. Retrieved from http://www.jstor.org/stable/3488872

6. Gyau, A., Mbugua, M., \& Oduol, J. (2016) Determinants of Participation and Intensity of Participation in Collective Action: Evidence from smallholder avocado farmers in Kenya, Journal on Chain and Network Science, 16(2), 147-156. doi.org/10.3920/JCNS2015.0011

7. Fischer, E. and Qaim, M. (2012) Gender, Agricultural Commercialization, and Collective Action in Kenya. Food Security, 4(3): 441-453. doi.org/10.1007/s12571-012-0199-7

8. Haggblade, S., Hazell, P., and Reardon, T. (2010). The rural non-farm economy: Prospects for growth and poverty reduction. World Development,38(10):1429-1441 doi: 10.1016/j.worlddev.2009.06.008

9. Horticultural Crop Directorate (2010), Export Statistics in Volumes and Values for Fresh Fruits, Vegetables and Flowers for the Year 2010

10. Horticultural Crop Directorate. (2016), Export Statistics in Volumes for Fresh Fruits, for the Year 2016

11. Ilahi, N. (2001). Gender and the Allocation of Adult Time: Evidence from the Peru LSMS Panel Data. Policy Research Working Paper; No.2744. World Bank, Washington, DC.World Bank. https://openknowledge.worldbank.org/handle/10986/19398 License: CC BY 3.0 IGO

12. Innocent $M$, and Young $T$ (2004). Off-Farm Labor Allocation Decisions in Small-Scale Rural Households in Zimbabwe. Agric. Econ.175-186. doi.org/10.1111/j.1574-0862.2004.tb00186.x 
13. Jones, A. (1989). A Double-Hurdle Model of Cigarette Consumption. Journal of Applied Econometrics, 4(1), 23-39. Retrieved from http://www.jstor.org/stable/2096488

14. Jones, A. M. (1992). A Note on Computation of the Double-Hurdle Model with Dependence with an Application to Tobacco Expenditure. Bulletin of economic Research, 44(1), 67-74. doi.org/10.1111/j.14678586.1992.tb00507.x

15. Kenya Institute for Public Policy Research and Analysis (KIPPRA, 2017). Kenya Economic Report 2017

16. Mutiso, A. (2017). Draft Report Literature Review: Contract Farming in Kenya. Mimeo Fresh Produce and Exporters Association of Kenya (FPEAK).

17. Mwambi, M. Oduol, J., Mshenga, P., and Saidi, M (2013). Does Contract Farming Improve Smallholder Farmers Income? The Case of Avocado Farming in Kenya. Invited paper presented at the 4th International Conference of the African Association of Agricultural Economists, September 22-25, 2013, Hammamet, Tunisia

18. NALEP (2009). Particular Assets and Vulnerabilities of Rural Women within the Agricultural Sector in Kenya

19. Newhouse, J. (1987). Health Economics and Econometrics. The American Economic Review, 77(2), 269-274. Retrieved from http://www.jstor.org/stable/1805462

20. Oduol, J. B. A., and Mithöfer, D. (2014). Constraints to and Opportunities for Women's Participation in High Value Agricultural Commodity Value Chains in Kenya (No. 2014/11).

21. OECD, (2008). Gender and Sustainable Development: Maximizing the Economic, Social and Environmental Role of Women. In: A Report to the United Nations Commission on Sustainable Development (UNCSD).

22. Omolo, P., Tana, P., Mutebi, C., Okwach, E., Onyango, H., and Okach, K. O. (2011). Analysis of Avocado Marketing in Trans-Nzoia District, Kenya, African Journal of Agricultural Marketing ISSN 2375-1061, 7 (2),

23. Republic of Kenya (2010). Agriculture Sector Development Strategy (ASDS) 2010-2012 Nairobi: Ministry of Agriculture

24. Schindler, K. (2008). Time Allocation, Gender and Norms: Evidence from Post-Genocide Rwanda. In Fourth Annual HiCN Workshop, Households in Conflict Network and Program on Order, Conflict and Violence, Yak University, New Haven Simtowe, F. and M. Zeller, (2007). The Impact of Access to Credit on the Adoption of Hybrid Maize in Malawi: An Empirical Test of an Agricultural Household 
Model under Credit Market Failure. EAAE Conference Proceedings, pp: 131-145

25. Sikei, G., J. Mburu \& J. Lagat (2009). Rural households Response to Fuelwood Scarcity around Kakamega Forest, Western Kenya. Paper presented at the 5th Bi-annual Conference of the United States Society for Ecological Economics (USSEE) at the American University, Washington DC, May $31^{\text {st }}$ to June $3^{\text {rd }} 2009$.

26. Tobin, J. (1958). Estimation of Relationships for Limited Dependent Variables. Econometrica, 26, 24-36 retrieved from https://www.jstor.org/stable/1907382

27. Wane, N. (2014). Indigenous African Knowledge Production: FoodProcessing Practices among Kenyan Rural Women. Toronto; Buffalo; London: University of Toronto Press. Retrieved from http://www.jstor.org/stable/10.3138/j.ctt6wrfwb 